\title{
Perancangan dan Realisasi Antena Mikrostrip Log Periodik dengan Elemen Parasitik Air Gap untuk Aplikasi TV Digital DVB-T2
}

\author{
INDRA SURJATI ${ }^{1}$, SYAH ALAM ${ }^{1}$, YULI KURNIA NINGSIH ${ }^{3}$
}

\author{
1,3Magister Teknik Elektro Universitas Trisakti \\ 2Jurusan Teknik Elektro Universitas Trisakti \\ Email: indra@trisakti.ac.id
}

Received 10 Desember 2018 | Revised 11 Februari 2019 | Accepted 24 Maret 2019

\begin{abstract}
ABSTRAK
Penelitian ini mengusulkan desain dan prototipe antena mikrostrip log periodik yang dikembangkan dengan metode parasitik air gap (celah udara) untuk aplikasi TV digital pada rentang frekuensi 478-694 MHz. Penggunaan elemen parasitik dengan celah udara bertujuan untuk meningkatkan nilai gain pada antena. Dari hasil pengukuran diperoleh nilai return loss sebesar -20.27 dB dan VSWR sebesar 1.31 pada frekuensi kerja $600 \mathrm{MHz}$. Bandwidth yang dihasilkan dari antena yang telah dipabrikasi adalah $273 \mathrm{MHz}$ dengan rentang frekuensi kerja $461 \mathrm{MHz}-734$ MHz. Gain yang dihasilkan dari antena mikrostrip log periodik dengan elemen parasitik adalah $16.67 \mathrm{~dB}$ pada frekuensi kerja $600 \mathrm{MHz}$ atau meningkat $40.02 \%$ dibandingkan dengan log periodik konvensional yang telah didesain sebelumnya. Dari keseluruhan hasil yang diperoleh maka dapat disimpulkan bahwa antena yang diusulkan dapat digunanakan sebagai antena penerima untuk aplikasi TV Digital di Indonesia.
\end{abstract}

Kata kunci: antena, mikrostrip, log periodik, parasitik, celah udara

\begin{abstract}
This study proposes the design and prototype of log periodic microstrip antenna which was developed using the parasitic air gap for digital TV applications with a frequency range of 478-694 MHz. The use of parasitic elements with air gap aims to increase the gain of the antenna. From the measurement results, proposed antenna obtained return loss of $-20.27 d B$ and VSWR of 1.31 at the working frequency of $600 \mathrm{MHz}$. The bandwidth produced from proposed antenna is 273 $\mathrm{MHz}$ with a working frequency range of $461 \mathrm{MHz}-734 \mathrm{MHz}$. The gain generated from log periodic microstrip antenna with parasitic element is $16.67 \mathrm{~dB}$ at the working frequency of $600 \mathrm{MHz}$ or increased $40.02 \%$ compared with conventional log periodic that have been designed before. From the overall results obtained, it can be concluded that the proposed antenna can be used as receiver antenna for Digital TV applications in Indonesia.
\end{abstract}

Keywords: antenna, microstrip, log periodic, parasitic, air gap 


\section{PENDAhULUAN}

Digital Video Broadcasting (DVB) adalah salah satu teknologi broadcasting yang banyak digunakan pada seluruh negara di dunia. Penggunaan teknologi TV digital di Indonesia telah ditetapkan oleh Kemenkominfo pada tahun 2011 yaitu untuk DVB-T (Digital Video Broadcasting-Teresterial ) (Kemenkominfo, 2011) dan dikembangkan menjadi DVB-T2 pada tahun 2012 (Kemenkominfo, 2012). Salah satu keunggulan dari penggunaan DVBT2 adalah alokasi frekuensi yang dibutuhkan menjadi lebih efisien jika dibandingkan dengan sistem analog. Selain itu, penerapan DVB-T2 juga menghasilkan kualitas gambar dan suara yang lebih baik jika dibandingkan dengan sistem konvensional yang digunakan sekarang ini (Kemenkominfo, 2012). Berdasarkan aturan yang ditetapkan oleh Kemenkominfo bahwa frekuensi kerja yang digunakan untuk aplikasi TV digital DVB-T2 yaitu pada rentang frekuensi 478-694 MHz dengan frekuensi tengah yaitu $586 \mathrm{MHz}$ (Kemenkominfo, 2011) .

Jenis antena yang banyak digunakan untuk sistem penerimaan televisi adalah jenis yaggi, hal ini dikarenakan antena jenis yaggi memiliki gain dan keterarahan yang lebih baik. Namun, dimensi dari antena yaggi cukup besar yaitu 1 meter sehingga sulit untuk diterapkan untuk penerima sistem televisi di dalam ruangan (indoor) (Candra, 2013). Untuk itu diperlukan suatu antena yang memiliki dimensi yang lebih kecil dan kompak sehingga dapat digunakan untuk sistem penerimaan TV Digital yang dapat ditempatkan dalam ruangan (indoor). Salah satu antena yang memiliki desain yang kecil dan kompak adalah antena mikrostrip. Kelebihan dari antena mikrostrip adalah dimensi yang kecil serta mampu bekerja pada frekuensi tinggi, selain itu antena mikrostrip juga mudah untuk dipabrikasi dengan biaya yang terjangkau. Namun, antena mikrostrip memiliki beberapa kelemahan yaitu gain yang kecil serta bandwidth yang sempit (Wong, 2004). Penelitian sebelumnya yang dilakukan oleh (Surjati I, Ningsih YK, Alam S, 2017) telah berhasil merancang dan merealisasikan antena mikrostrip dengan metode log periodik untuk aplikasi TV Digital dengan bandwidth sebesar $350 \mathrm{MHz}$ dengan gain $11.62 \mathrm{~dB}$ pada frekuensi kerja $586 \mathrm{MHz}$.

Penelitian ini bertujuan untuk meningkatkan nilai gain pada antena mikrostrip log periodik yang telah dirancang dan direalisasi sebelumnya (Surjati I, Ningsih YK, Alam S, 2017). Beberapa metode untuk meningkatkan nilai gain telah diusulkan oleh peneliti sebelumnya yaitu dengan metode parasitik pada antena mikrostrip bentuk lingkaran dengan celah udara yang dilakukan oleh (Mrnka M, Raida Z, 2016) dengan dapat meningkatkan nilai gain antena dari $11.6 \mathrm{dBi}$ menjadi $13.2 \mathrm{dBi}$, selain itu metode array yang dilakukan oleh (Wijanto E, Alam S, Harsono B, 2018) dapat meningkatkan nilai gain sebesar $45.07 \%$ dibanding dengan antena elemen tunggal. Metode array yang diterapkan oleh (Alam, S., Wibisana, I. G. N. Y., \& Surjati, I., 2017) juga terbuti dapat meningkatkan nilai gain antena dari $4.87 \mathrm{dBi}$ menjadi $6.44 \mathrm{dBi}$ dengan menggunakan 4 elemen yang disusun sejajar. Peningkatan nilai gain dari $1.625 \mathrm{~dB}$ menjadi $4.117 \mathrm{~dB}$ juga diperoleh pada penelitian yang dilakukan oleh (Teguh Firmansyah, Herudin, Romi Wiryadinata, M.Iman Santoso, Yus Rama Denny, Toto Supriyanto, 2017) dengan menggunakan parasitik air gap bentuk lingkaran untuk frekuensi kerja $2.35 \mathrm{GHz}$ sedangkan pada penelitian yang dilakukan oleh (Jacob Abraham, Thomaskutty Mathew, Chandroth K. Aanandan, 2016) dapat meningkatkan gain sebesar $1.85 \mathrm{~dB}$ pada frekuensi kerja $2.584 \mathrm{MHz}$. Pada penelitian ini metode yang digunakan untuk meningkatkan nilai gain adalah metode parasitik dengan menggunakan celah udara sebagai pemisah antara elemen peradiasi yang berbentuk log periodik pada side PCB bagian bawah dengan elemen parasitik yang berada di side PCB bagian atas. Jarak celah udara dengan elemen peradiasi akan dioptimasi untuk memperoleh nilai gain terbaik. Jenis substrat yang digunakan untuk layer elemen peradiasi dan elemen parastik adalah sama yaitu menggunakan jenis FR-4. Penggunaan metode ini bertujuan 
untuk menghasilkan dimensi antena yang kecil jika dibandingkan dengan menggunakan metode array yang akan membuat dimensi antena menjadi jauh lebih besar. Target dari penelitian ini adalah menghasilkan antena mikrostrip yang bekerja pada frekuensi 478-694 $\mathrm{MHz}$ dengan nilai return loss $\leq-10 \mathrm{~dB}$ dan VSWR $\leq 2$ serta memiliki nilai gain $15 \mathrm{~dB}$. Keterbaruan dalam penelitian ini adalah bentuk serta dimensi dari elemen parasitik yang digunakan yaitu berbentuk kotak dengan slot di bagian tengahnya yang ditempatkan di bagian atas elemen peradiasi dan dipisahkan oleh celah udara sejauh jarak celah udara (d). Target penguatan (gain) disesuaikan dengan kebutuhan antena penerima untuk aplikasi TV Digital yang tersedia di pasaran yaitu $10-20 \mathrm{~dB}$. Desain dan realisasi dari antena yang diusulkan diharapkan dapat diterapkan sebagai antena penerima pada komunikasi TV Digital di Indonesia.

\section{DESAIN ANTENA}

\subsection{Metode Perancangan}

Pada penelitian ini, perancangan awal dilakukan dengan mendesain elemen peradiasi yang berbentuk log periodik. Material substrat yang digunakan adalah jenis FR-4 Epoxy dengan spesifikasi yang ditunjukkan pada Tabel 1 (Surjati, 2010). Penggunaan substrat ini bertujuan untuk menghasilkan dimensi antena yang kecil karena substrat jenis FR-4 memiliki nilai konstanta dielektrik (Er) yang besar yaitu 4.3 dan ketebalan bahan (h) $1.6 \mathrm{~mm}$, di samping itu bahan jenis FR-4 lebih mudah ditemukan di pasaran dan harganya terjangkau. Namun kekurangan susbtrat ini adalah memiliki loss (tan $\delta$ ) yang cukup besar yaitu 0.0265 sehingga akan mereduksi kinerja dari antena rancangan.

Tabel 1. Spesifikasi Substrat FR-4 Epoxy

\begin{tabular}{|c|c|}
\hline Jenis Substrat & FR-4 Epoxy \\
\hline Konstanta Dielektrik Relatif $(\varepsilon r)$ & 4.3 \\
\hline Konstanta Permeabilitas Relatif $(\mu r)$ & 1 \\
\hline Dielectric Loss Tangent $(\tan \delta)$ & 0.0265 \\
\hline Ketebalan Substrat $(\mathrm{h})$ & $1.6 \mathrm{~mm}$ \\
\hline
\end{tabular}

Setelah diperoleh dimensi elemen peradiasi yang berbentuk antena mikrostrip maka tahapan selanjutnya adalah mendesain elemen parasitik yang akan ditempatkan di bagian atas dari elemen peradiasi dengan dipisahkan menggunakan celah udara sejauh jarak celah udara (d). Celah udara berfungsi untuk menghasilkan electromagnetic band gap yang akan menyebabkan terjadinya peningkatan nilai gain dan bandwidth pada antena mikrostrip. Susbtrat bagian atas $\left(\varepsilon_{\mathrm{r} 1}\right)$ yang diisi oleh elemen peradiasi dipabrikasi menggunakan substrat FR-4 single side sedangkan untuk elemen parasitik menggunakan substrat double side $\left(\varepsilon_{\mathrm{r}_{2}}\right)$ dengan lapisan tembaga di bagian belakang sebagai grounding. Ilustrasi gambar susunan substrat dan penempatan elemen parasitik dapat dilihat pada Gambar 1.

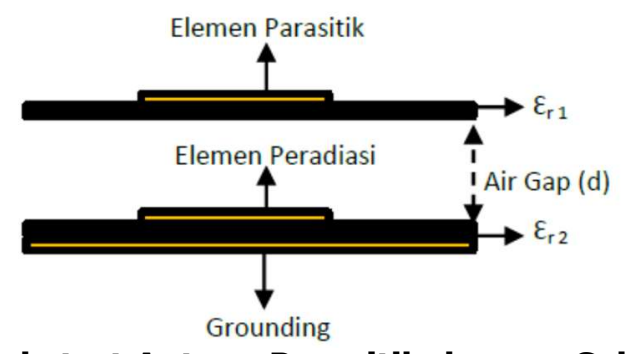

Gambar 1. Susunan Substrat Antena Parasitik dengan Celah Udara (Air Gap) 
Perancangan dan Realisasi Antena Mikrostrip Log Periodik dengan Elemen Parasitik Air Gap untuk Aplikasi TV Digital DVB-T2

Diagram alir dari perancangan dan realisasi antena mikrostrip dengan parasitik dapat dilihat pada Gambar 2.

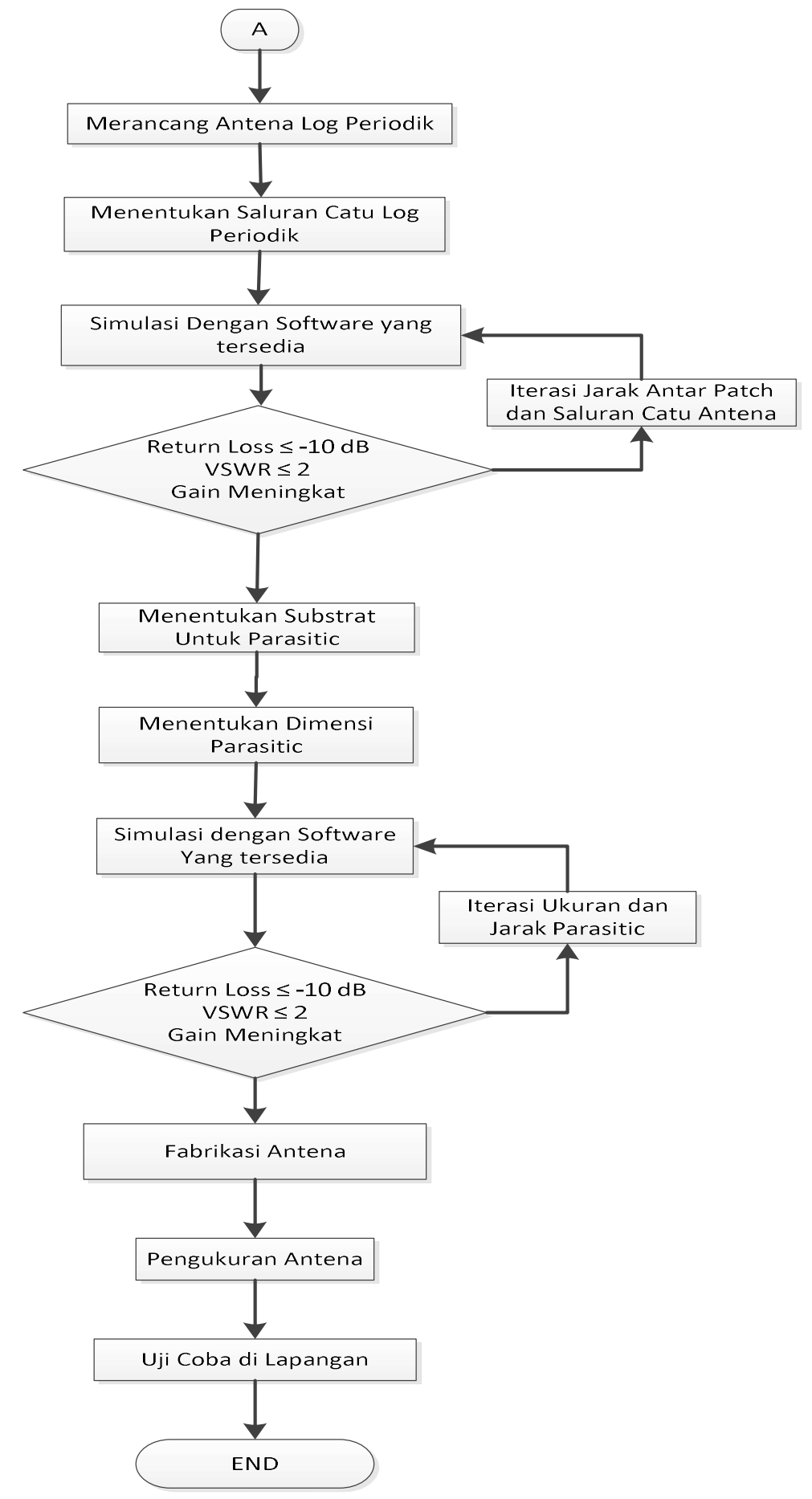

Gambar 2. Diagram Alir Perancangan Antena

\subsection{Desain Antena Mikrostrip Log Periodik}

Desain antena mikrostrip log periodik yang digunakan pada penelitian diperoleh dengan menggunakan Persamaan (1), (2), (3), (4) dan (5) (Stutzman WL, Thiele GA, 2013). Desain awal dari antena mikrostrip adalah bentuk persegi panjang dengan $W$ dan $L$ dan saluran pencatu dengan nilai impedansi 50 Ohm sesuai dengan konektor yang digunakan. 


$$
\begin{gathered}
\mathrm{W}=\frac{C}{2 f \sqrt{\frac{\varepsilon r+1}{2}}} \\
\mathrm{~L}=\mathrm{L}_{\text {eff }}-2 \Delta \mathrm{L} \\
L_{e f f}=\frac{C}{2 f \sqrt{\varepsilon_{\text {reff }}}} \\
\varepsilon_{\text {reff }}=\frac{\varepsilon r+1}{2}+\frac{\varepsilon r-1}{2}\left[1+12 \frac{h}{W}\right]^{-\frac{1}{2}} \\
\Delta L=0,412 h \frac{\left(\varepsilon_{\text {reff }}+0.3\right)\left(\frac{W}{h}+0.264\right)}{\left(\varepsilon_{\text {reff }}-0.258\right)\left(\frac{W}{h}+0.8\right)}
\end{gathered}
$$

Prinsip desain untuk log periodik membutuhkan penskalaan dimensi dari periode ke periode sehingga kinerja periodik dengan logaritma frekuensi. Panjang (Ln) dan lebar (Wn) dari resonator patch dari log microstrip antena periodik meningkat sepanjang array oleh faktor $\tau$ di mana $\tau$ dapat dihitung dengan Persamaan (6) (Rahim, M. K. A., \& Gardner, P., 2004).

$$
\tau=\frac{L n+1}{L n}=\frac{W n+1}{W n}
$$

Desain antena log periodik yang dikembangkan dengan metode peripheral slit pada penelitian ini telah diteliti sebelumnya dan dipabrikasi oleh (Surjati I, Ningsih YK, Alam S, 2017), tampilan dari antena mikrostrip dengan log periodik dengan 4 elemen dapat dilihat pada Gambar 3. Tiap-tiap elemen pada antena mikrostrip log periodik memiliki frekuensi yang berbeda sehingga dapat bekerja pada frekuensi $478 \mathrm{MHz}$ - $694 \mathrm{MHz}$ untuk aplikasi TV Digital.

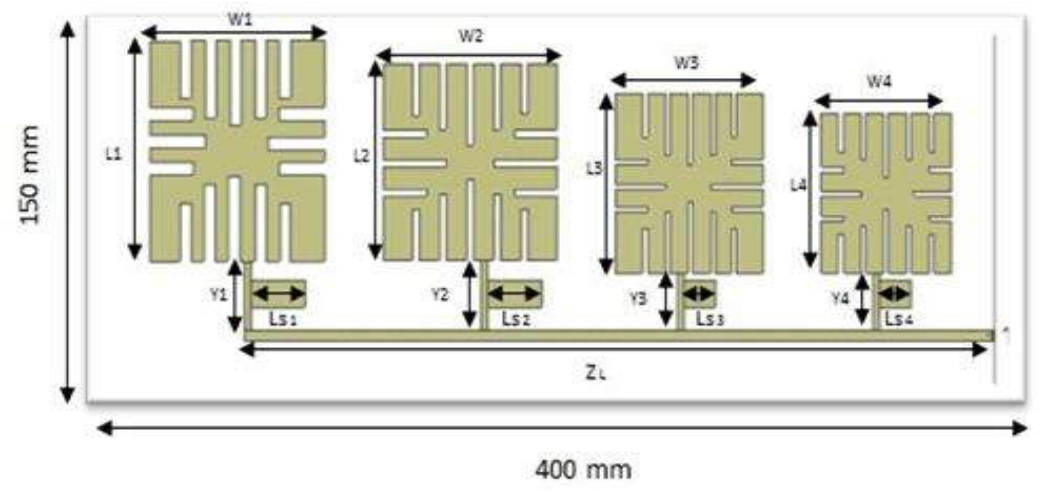

Gambar 3. Desain Antena Mikrostrip dengan Log Periodik

Dari Gambar 3 dapat dilihat dengan jelas bahwa antena log periodik memiliki 4 elemen dengan ukuran yang berbeda. Patch 1 memiliki dimensi W1 $=77,4 \mathrm{~mm}, \mathrm{~L} 1=89,5 \mathrm{~mm}, \mathrm{Y} 1=$ $27,8 \mathrm{~mm}$ dan $\mathrm{Ls} 1=24 \mathrm{~mm}$. Patch 2 memiliki dimensi $\mathrm{W} 2=77 \mathrm{~mm}, \mathrm{~L} 2=80 \mathrm{~mm}, \mathrm{Y} 2=28$ $\mathrm{mm}$ dan $\mathrm{Ls} 2=24 \mathrm{~mm}$. Patch 3 memiliki dimensi $\mathrm{W} 3=65 \mathrm{~mm}, \mathrm{~L} 3=73 \mathrm{~mm}, \mathrm{Y} 3=23 \mathrm{~mm}$ dan $\mathrm{Ls} 3=14 \mathrm{~mm}$ dan patch 4 memiliki dimensi $\mathrm{W} 4=58 \mathrm{~mm}, \mathrm{~L} 4=65 \mathrm{~mm}, \mathrm{Y} 4=23 \mathrm{~mm}$ dan Ls4 $=14 \mathrm{~mm}$. Dimensi saluran mikrostrip dari antena log periodik adalah ZL $=332,6$ $\mathrm{mm}$.

\subsection{Desain Elemen Parasitik dengan Celah Udara}

Setelah desain antena log periodik diperoleh, tahapan selanjutnya adalah merancang beban parasitik yang berfungsi untuk meningkatkan nilai gain. Dimensi parasitik adalah sama 
dengan dimensi antena log periodik, namun di bagian tengahnya diberikan slot berbentuk kotak agar dapat menghasilkan gain yang maksimal. Jarak celah udara (d) antara elemen peradiasi dan elemen parasitik adalah $2 \mathrm{~mm}$. Desain elemen parasitik pada antena log periodik dapat dilihat pada Gambar 4.

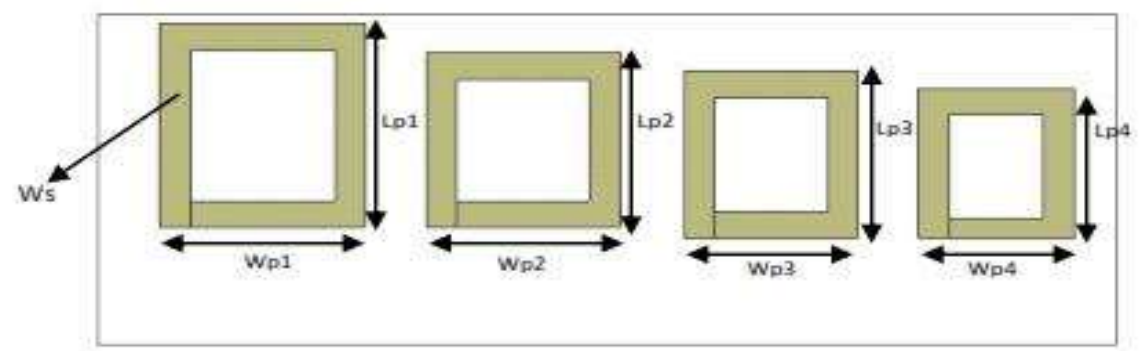

Gambar 4. Desain Elemen Parasitik

Dari Gambar 4 dapat dilihat dimensi panjang dan lebar dari antena parasitik identik dengan patch log periodik dimana Wp1 $=80,5 \mathrm{~mm}, \mathrm{Wp} 2=76 \mathrm{~mm}, \mathrm{Wp} 3=68 \mathrm{~mm}$ dan Wp4 $=58$ $\mathrm{mm}$ sementara $\mathrm{Lp} 1=89,5 \mathrm{~mm}$, Lp2 $=80 \mathrm{~mm}$, Lp3 $=73 \mathrm{~mm}$, Lp4 $=65 \mathrm{~mm}$. Desain keseluruhan dari antena log periodik dengan elemen parasitik dapat dilihat pada Gambar 5.

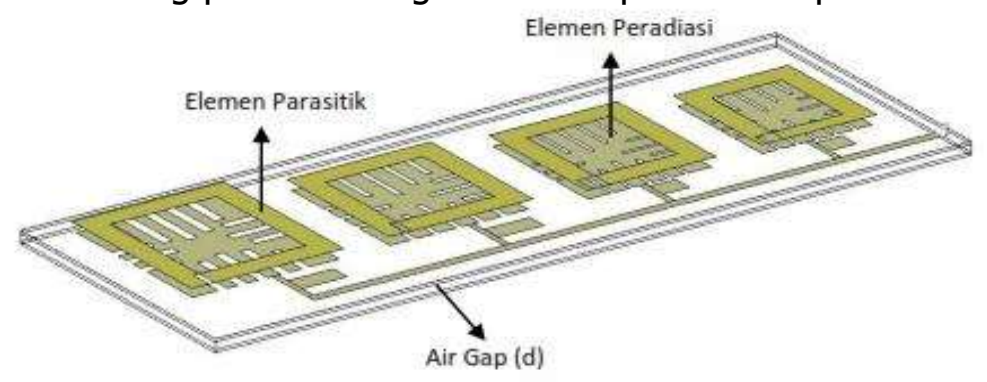

Gambar 5. Desain Antena Log Periodik dengan Elemen Parasitik

\section{HASIL PERANCANGAN DAN REALISASI}

\subsection{Hasil Simulasi Antena Mikrostrip Log Periodik dengan Elemen Parasitik}

Setelah dilakukan proses perancangan antena mikrostrip log periodik dengan elemen parasitic, maka tahapan selanjutnya adalah melakukan simulasi menggunakan perangkat lunak AWR Microwave Office 2009 untuk melihat kinerja dari parameter antena rancangan. Untuk memperoleh bandwidth dan gain yang maksimal pada antena rancangan maka dilakukan iterasi terhadap lebar Slot (Ws) pada elemen parasitik dan jarak celah udara (d). Adapun hasil simulasi return loss dan VSWR antena rancangan yang diperoleh dari proses iterasi terhadap lebar Slot(Ws) dapat dilihat pada Gambar 6 dan Gambar 7.

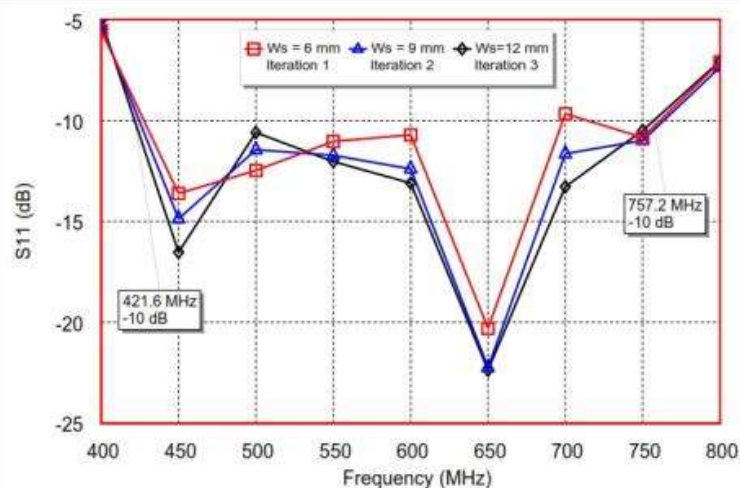

Gambar 6. Simulasi Return loss Iterasi Ws

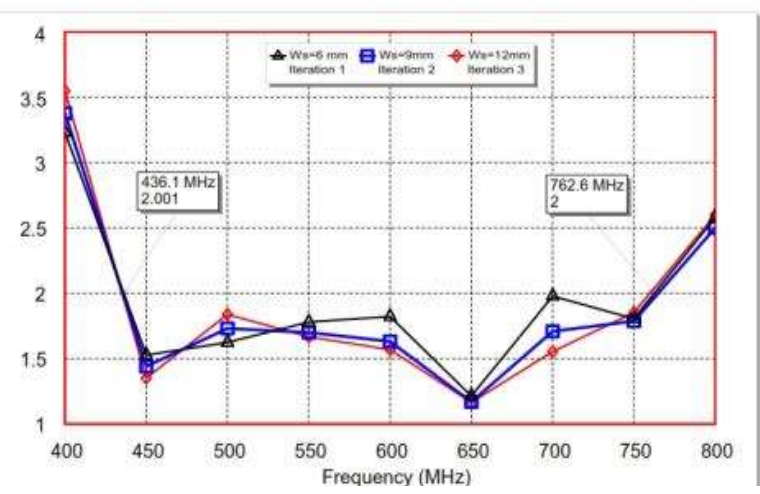

Gambar 7. Simulasi VSWR Iterasi Ws 
Dari Gambar 6 dan Gambar 7 dapat dilihat bahwa ukuran dimensi slot mempengaruhi nilai return loss dan VSWR pada desain antena. Hasil terbaik diperoleh pada proses iterasi ketiga dimana Ws $=12 \mathrm{~mm}$ dengan return loss value $\leq-10 \mathrm{~dB} \mathrm{~dB}$ dan VSWR $\leq 2$ pada rentang frekuensi kerja $421 \mathrm{MHz}-757 \mathrm{MHz}$ dengan bandwidth $339 \mathrm{MHz}$. Hasil keseluruhan dari proses simulasi dapat dilihat pada Tabel 2.

Tabel 2. Bandwidth dari Hasil Iterasi Ws

\begin{tabular}{|c|c|c|c|}
\hline No & Iterasi & Dimensi (Ws) & Bandwidth \\
\hline 1. & Pertama & $6 \mathrm{~mm}$ & $270.7 \mathrm{MHz}$ \\
\hline 2. & Kedua & $9 \mathrm{~mm}$ & $330 \mathrm{MHz}$ \\
\hline 3. & Ketiga & $12 \mathrm{~mm}$ & $339 \mathrm{MHz}$ \\
\hline
\end{tabular}

Untuk memperoleh nilai bandwidth dan gain maksimal maka dilakukan iterasi pada jarak celah udara (d) pada antena rancangan. Hasil simulasi return loss dan VSWR dari proses iterasi jarak celah udara (d) pada antena rancangan dapat dilihat pada Gambar 8 dan Gambar 9 di bawah ini.

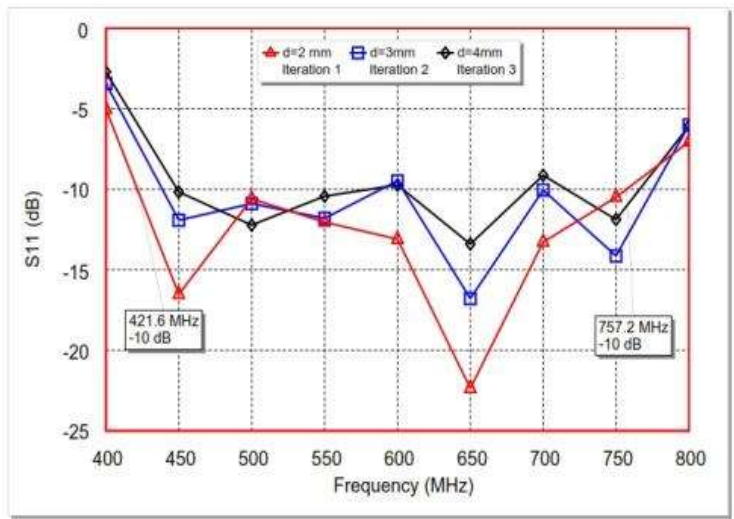

Gambar 8. Simulasi Return Loss Iterasi d

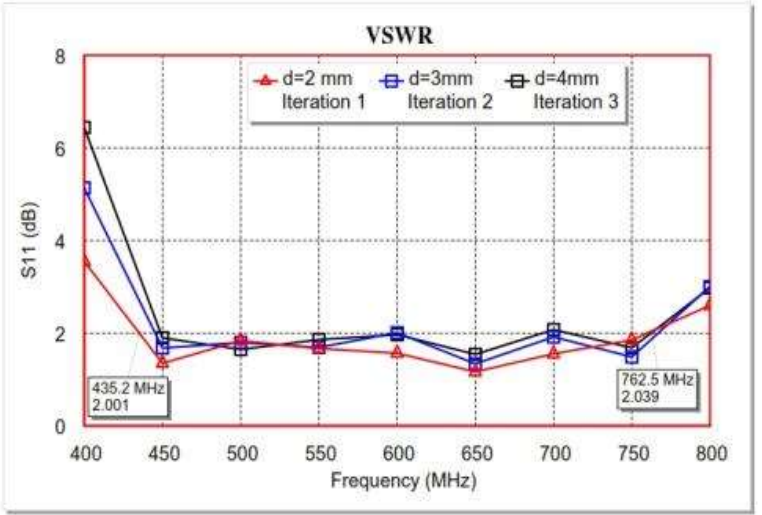

Gambar 9. Simulasi VSWR Iterasi d

Dari Gambar 8 dan Gambar 9 dapat dilihat bahwa hasil simulasi yang optimal diperoleh pada saat $\mathrm{d}=2 \mathrm{~mm}$ dengan nilai return loss $\leq-10 \mathrm{~dB}$ dan VSWR $\leq 2$ pada rentang frekuensi kerja $421 \mathrm{MHz}-757 \mathrm{MHz}$ dengan bandwidth $339 \mathrm{MHz}$. Hasil keseluruhan dari proses iterasi air gap dapat dilihat pada Tabel 3 di bawah ini.

Tabel 3. Bandwidth dari Hasil Iterasi Jarak Celah Udara (d)

\begin{tabular}{|c|c|c|c|}
\hline No & Iterasi & Dimensi (d) & Bandwidth \\
\hline 1. & Pertama & $2 \mathrm{~mm}$ & $339 \mathrm{MHz}$ \\
\hline 2. & Kedua & $3 \mathrm{~mm}$ & $164.8 \mathrm{MHz}$ \\
\hline 3. & Ketiga & $4 \mathrm{~mm}$ & $127 \mathrm{MHz}$ \\
\hline
\end{tabular}

\subsection{Hasil Pabrikasi dan Pengukuran Antena Mikrostrip}

Setelah memperoleh hasil simulasi yang maksimal, maka tahapan selanjutnya adalah melakukan proses pabrikasi dari antena hasil rancangan. Pabrikasi dilakukan dengan menggunakan PCB jenis FR-4 yang dihubungkan dengan konektor SMA-Female sebagai pencatu untuk keluaran antena. Untuk antena log periodik menggunakan substrat double side dimana bagian bawahnya terdapat tembaga yang berfungsi sebagai ground, sedangkan untuk elemen parasitik menggunakan substrat single side dimana pada bagian bawah antena tidak terdapat tembaga. Adapun desain antena log periodik dapat dilihat pada Gambar 10 
dan desain elemen parasitik pada Gambar 11. Untuk desain keseluruhan antena hasil rancangan dapat dilihat pada Gambar 12.

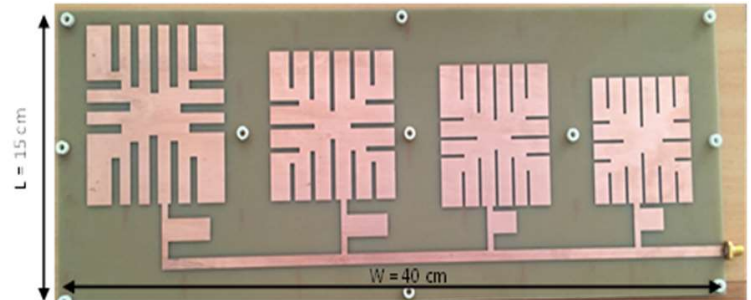

(a) Bagian Atas

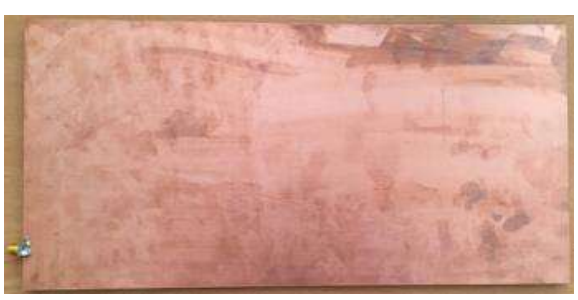

(b) Bagian Bawah

Gambar 10. Hasil Pabrikasi Antena Mikrostrip Log Periodik (a) Bagian Atas; (b) Bagian Bawah

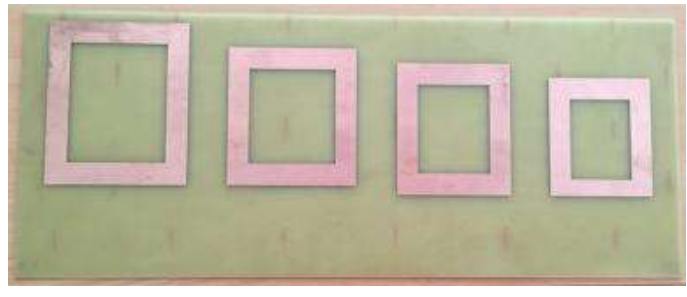

(a) Bagian Atas

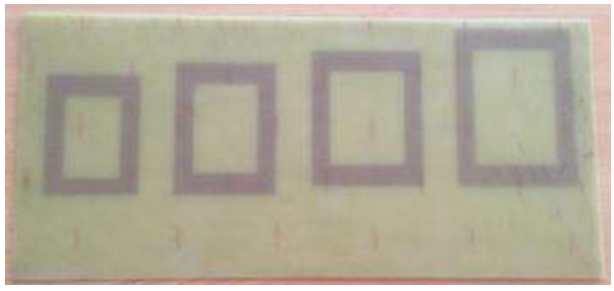

(b) Bagian Bawah

Gambar 11. Hasil Pabrikasi Elemen Parasitik (a) Bagian Atas; (b) Bagian Bawah

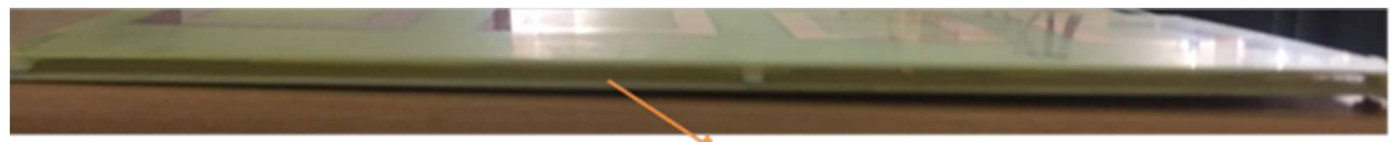

Air Gap (d) $=2 \mathrm{~mm}$

\section{Gambar 12. Penggabungan dan Penyusunan Antena Log Periodik dan Elemen Parasitik dengan Celah Udara}

Setelah dilakukan pabrikasi terhadap desain antena log periodik dan elemen parasitik, tahapan selanjutnya adalah menyusun kedua elemen antena tersebut yang dipisahkan oleh celah udara (air gap) dengan jarak $\mathrm{d}=2 \mathrm{~mm}$. Antena log periodik dan elemen parasitik dipisahkan menggunakan penyangga dengan bahan plastik dengan jarak celah yaitu $2 \mathrm{~mm}$. Penggunaan penyangga dengan bahan plastik bertujuan untuk memberi celah udara dan juga bahan jenis plastik lebih aman terhadap interferensi gelombang dibandingkan dengan penyangga berbahan dasar besi/alumunium.

\subsection{Hasil Pengukuran Antena Mikrostrip}

Pengukuran return loss dilakukan dengan menggunakan alat ukur Vector Network Analyzer merk ADVANTEST dengan rentang frekuensi kerja $300 \mathrm{MHz}-1000 \mathrm{MHz}$. Pengukuran ini dilakukan di laboratorium antena dan propagasi di PPET LIPI Bandung. Hasil pengukuran return loss dari antena yang di usulkan dapat dilihat pada Gambar 13, 14 dan 15. 


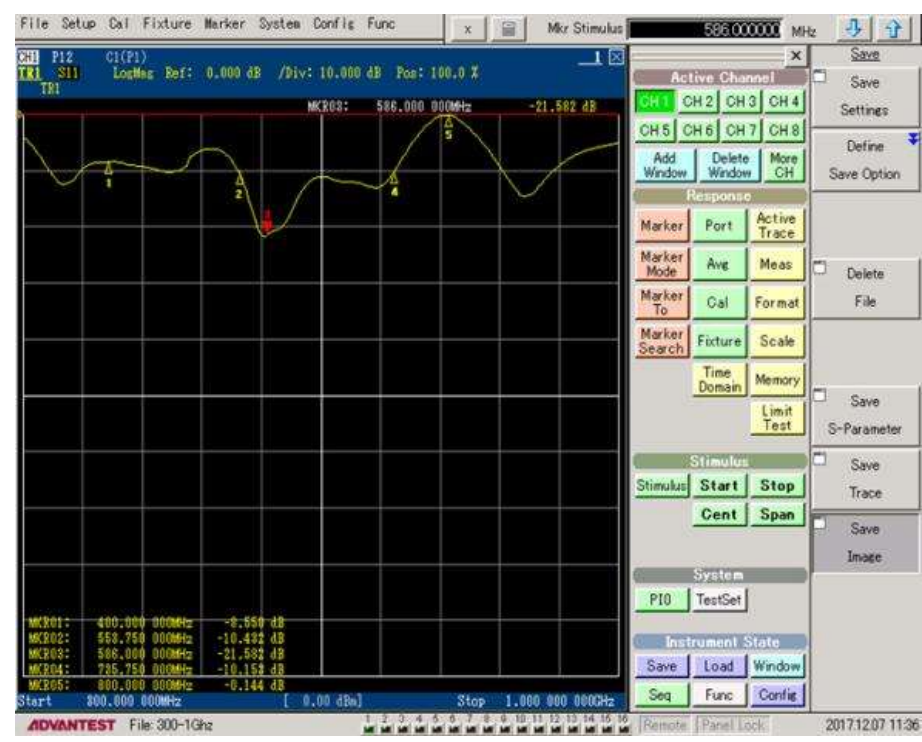

Gambar 13. Hasil Pengukuran Return loss dari Antena Hasil Rancangan

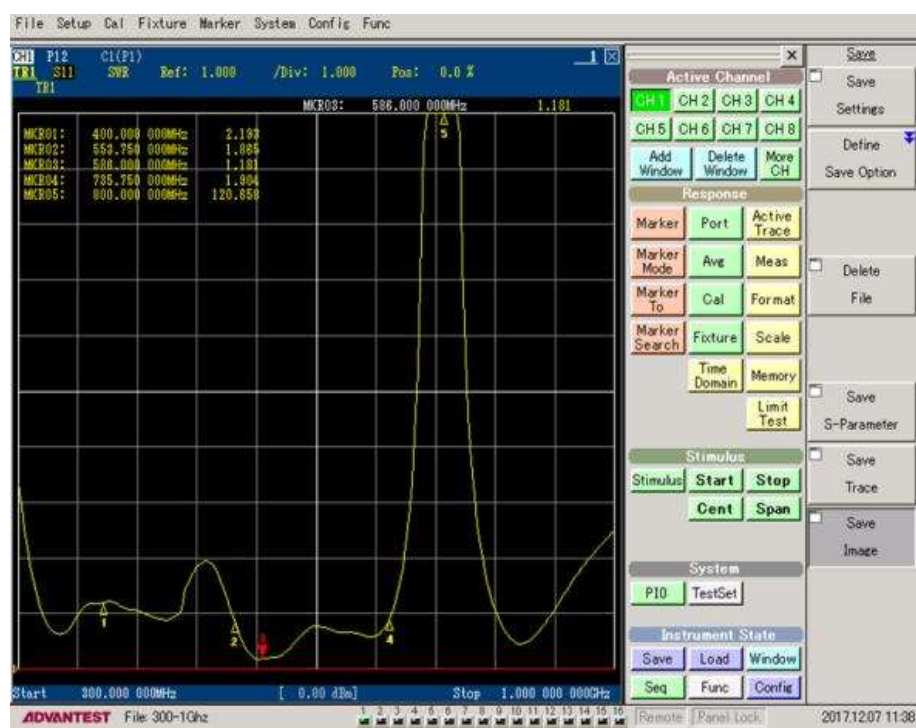

Gambar 14. Hasil Pengukuran VSWR dari Antena Hasil Rancangan

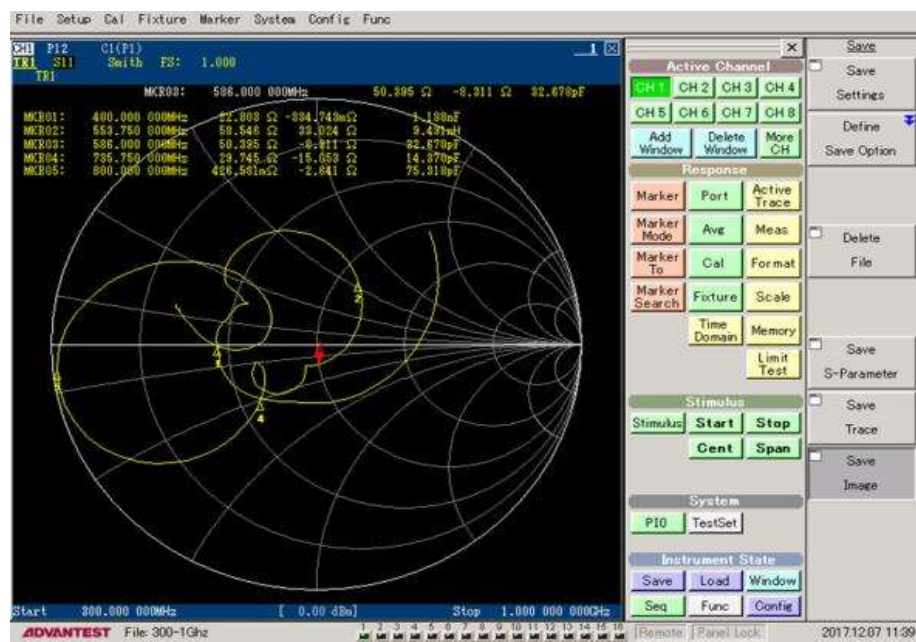

Gambar 15. Hasil Pengukuran Impedansi (Zin) pada Antena Hasil Rancangan 
Dari Gambar 13 dan Gambar 14 dapat dilihat bahwa antena yang diusulkan menghasilkan nilai return loss $\leq-10 \mathrm{~dB}$ pada rentang frekuensi $461 \mathrm{MHz}-734 \mathrm{MHz}$. Bandwidth yang dihasilkan dari antena mikrostrip yang diusulkan adalah $273 \mathrm{MHz}$. Dari Gambar 15 dapat dilihat bahwa nilai impedansi antena yang dipabrikasi sudah mendekati 50 Ohm yaitu 50.35 - j 8.113 pada frekuensi kerja $586 \mathrm{MHz}$ untuk aplikasi TV Digital. Hal ini menunjukkan bahwa antena memiliki nilai impedansi yang baik dan sesuai dengan impedansi outputnya. Dari keseluruhan hasil proses pengukuran $\mathrm{S}_{11}$ (return loss, VSWR dan impedansi) antena yg dirancang telah memenuhi syarat untuk dapat diaplikasikan untuk TV Digital pada rentang ferkuensi 478-694 MHz.

Selain itu, untuk melihat kinerja gain dan pola radiasi antena rancangan dilakukan proses pengukuran pada ruang anechoic chamber. Pengukuran antena mikrostrip dilakukan di Lab Antena dan Propagasi PPET LIPI Bandung dengan menggunakan perangkat frequency generator sebagai pembangkit sinyal dan spectrum analyzer sebagai penerima sinyal. Untuk antena pembanding digunakan jenis horn dengan gain $12 \mathrm{dBi}$. Konfigurasi pengukuran pola radiasi pada antena mikrostrip dapat dilihat pada Gambar 16 (b) dibawah ini. Antena yang dirancang diposisikan sebagai antena penerima yang sudut azimuth-nya akan digeser secara bertahap dari $0^{\circ}$ sampai dengan $360^{\circ}$. Hasil pengukuran pola radiasi pada ruang anechoic chamber dari antena rancangan dapat dilihat pada Gambar 16 (a).

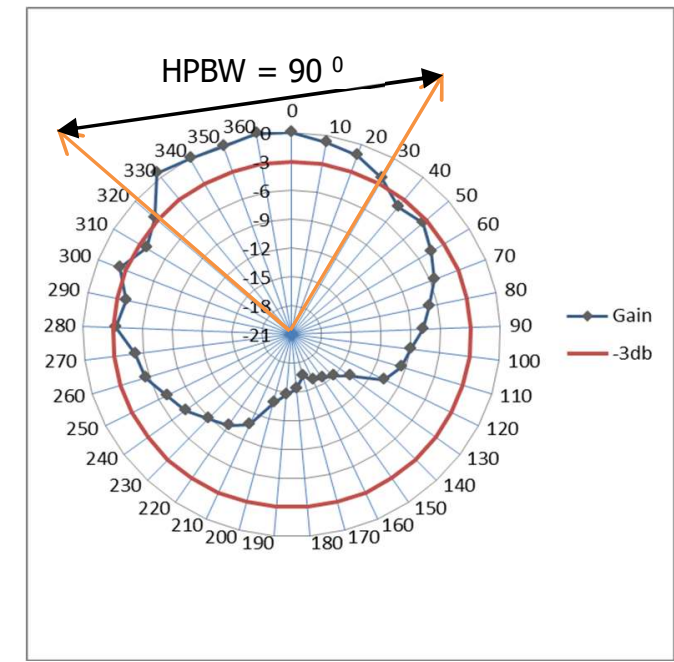

(a) Hasil Pengukuran Pola Radiasi

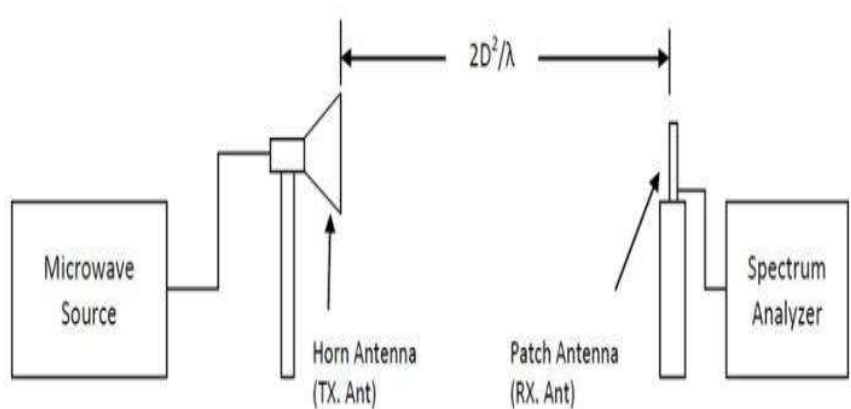

(b) Konfigurasi Pengukuran Pola Radiasi

\section{Gambar 16. Pengukuran Pola Radiasi}

Dari Gambar 16 (a) dapat dilihat bahwa antena yang dirancang menghasilkan pola radiasi directional / satu arah dengan sudut berkas pancaran / Half Power Beamwidth (HPBW) sebesar $90^{\circ}$ dari rentang sudut $320^{\circ}$ sampai dengan $30^{\circ}$. Hal ini menunjukkan antena yang dirancang memiliki pola pancar yang cukup lebar untuk menerima sinyal yang masuk dari pemancar TV Digital. Selain itu dilakukan pengukuran gain untuk melihat kinerja dari antena mikrostrip yang telah dirancang. Dari hasil pengukuran antena mikrostrip yang dilakukan di laboratorium antena dan propagasi PPET LIPI Bandung, diperoleh hasil sebagai berikut. Gain diukur pada frekuensi kerja $600 \mathrm{MHz}$ dengan power $0 \mathrm{~dB}$ dari function generator dan dapat dihitung dengan menggunakan Persamaan (7). 


$$
\text { Gain (pengukuran) : } \mathrm{P}_{1}(\mathrm{Rx})-\mathrm{P}_{2}(\mathrm{Tx})+\mathrm{G}_{\mathrm{ref}}
$$

Dimana :

$P_{1}(R x)=$ saat antena rancangan sebagai penerima

$P_{2}(T x)=$ saat antena rancangan sebagai pemancar

$\mathrm{G}_{\text {ref }} \quad=$ antena referensi, dimana gain-nya telah diketahui $12 \mathrm{~dB}$

Dari hasil pengukuran menggunakan spectrum analyzer terhadap antena hasil perancangan pada ruang anechoic chamber dengan antena pembanding tipe horn yang bekerja pada frekuensi kerja $3 \mathrm{GHz}-15 \mathrm{GHz}$ dengan penguatan $12 \mathrm{~dB}$. Pada proses pengukuran diperoleh nilai pengukuran level penerimaan sinyal seperti yang ditunjukkan pada Tabel 4.

Tabel 4. Hasil Pengukuran Level Penerimaan Sinyal pada Ruang Anechoic Chamber

\begin{tabular}{|c|c|c|c|}
\hline \multirow[t]{2}{*}{ No } & \multirow{2}{*}{$\begin{array}{c}\text { Sudut } \\
\text { Penerimaan }\end{array}$} & \multicolumn{2}{|c|}{ Level Penerimaan } \\
\hline & & Antena Rancangan $P_{1}(\mathbf{R x})$ & Antena Pembanding $\mathbf{P}_{2}$ (Tx) \\
\hline 1. & $0^{0}$ & $-43.85 \mathrm{~dB}$ & $-48.12 \mathrm{~dB}$ \\
\hline 2. & $90^{0}$ & $-51.68 \mathrm{~dB}$ & $-49.27 \mathrm{~dB}$ \\
\hline 3. & $180^{0}$ & $-59.23 \mathrm{~dB}$ & $-49.13 \mathrm{~dB}$ \\
\hline 4. & $360^{0}$ & $-43.65 \mathrm{~dB}$ & $-48.32 \mathrm{~dB}$ \\
\hline
\end{tabular}

Dari Tabel 4, dapat dilihat bahwa antena hasil rancangan memiliki level penerimaan terbaik pada sudut $0^{\circ}$ dengan nilai $-43.85 \mathrm{~dB}$ pada saat antena rancangan jadi penerima dan -48.12 $\mathrm{dB}$ pada saat menjadi pemancar. Nilai gain dapat dihitung dengan menggunakan Persamaan (7) dengan gain referensi antena pembanding $12 \mathrm{~dB}$.

Gain (pengukuran) $=-43.85 \mathrm{dBm}-(-48.12 \mathrm{dBm})+12 \mathrm{~dB}$

$$
=16.27 \mathrm{~dB}
$$

\subsection{Perbandingan Hasil Pengukuran dengan Simulasi}

Dari hasil simulasi dan pengukuran yang telah dilakukan maka dapat dianalisis tingkat kesalahan dari parameter antena yang telah dipabrikasi. Perbandingan hasil simulasi dan pengukuran parameter return loss pada antena mikrostrip yang telah dipabrikasi dapat dilihat pada Gambar 17 .

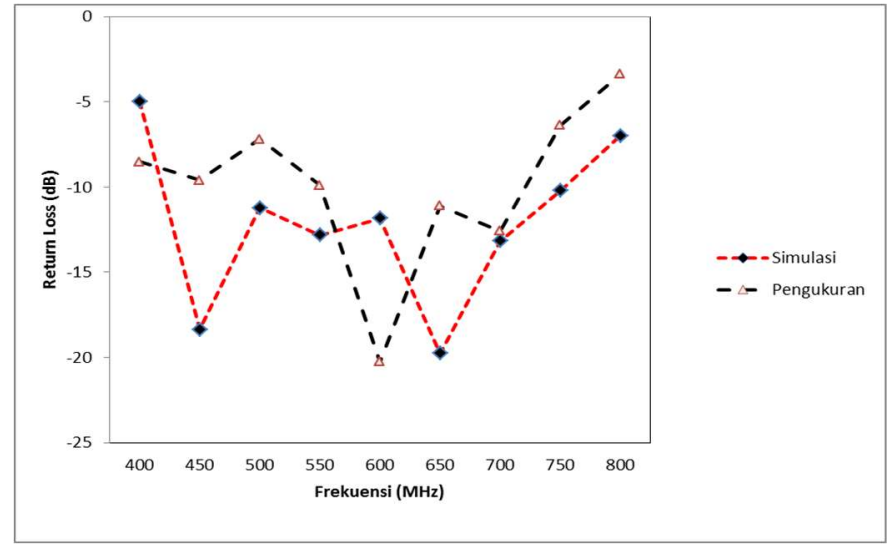

Gambar 17. Perbandingan Hasil Simulasi dan Pengukuran Return Loss

Dari Gambar 17 dapat dilihat bahwa hasil pengukuran dari antena mikrostrip yang telah dipabrikasi memiliki perbedaan dengan hasil simulasi. Perbandingan secara keseluruhan dari 
proses simulasi dan pengukuran parameter return loss dari antena yang telah dipabrikasi dapat dilihat pada Tabel 5.

Tabel 5. Perbandingan Hasil Simulasi dan Pengukuran Return loss

\begin{tabular}{|c|c|c|c|}
\hline No & Frequency (MHz) & \multicolumn{2}{|c|}{ Nilai Return loss (dB) } \\
\cline { 3 - 4 } & & Pengukuran & Simulasi \\
\hline 1. & 400 & -8.52 & -4.96 \\
\hline 2. & 450 & -9.60 & -18.37 \\
\hline 3. & 500 & -7.19 & -11.23 \\
\hline 4. & 550 & -9.89 & -12.83 \\
\hline 5. & 600 & -20.27 & -11.85 \\
\hline 6. & 650 & -11.10 & -19.76 \\
\hline 7. & 700 & -12.57 & -13.17 \\
\hline 8. & 750 & -6.38 & -10.22 \\
\hline 9. & 800 & -3.38 & -6.99 \\
\hline
\end{tabular}

Dari Gambar 17 dan Tabel 5 dapat dianalisis bahwa pada frekuensi yang mendekati 586 $\mathrm{MHz}$ yaitu $600 \mathrm{MHz}$ hasil pengukuran memiliki return loss lebih baik daripada hasil simulasi. Pada proses simulasi diperoleh nilai return loss sebesar $-11.85 \mathrm{~dB}$ sedangkan dari hasil pengukuran diperoleh nilai return loss sebesar -20.27 dB. Untuk bandwidth yang dihasilkan dari proses pengukuran menjadi lebih sempit dibandingkan dengan proses simulasi. Perbandingan bandwidth dari proses pengukuran dan simulasi dapat dilihat pada Tabel 6.

Tabel 6. Perbandingan Bandwidth Simulasi dan Pengukuran

\begin{tabular}{|c|c|}
\hline Bandwidth Hasil Simulasi & Bandwidth Hasil Pengukuran \\
\hline $339 \mathrm{MHz}(421-757 \mathrm{MHz})$ & $273 \mathrm{MHz}(461 \mathrm{MHz}-734 \mathrm{MHz})$ \\
\hline
\end{tabular}

Dari hasil data yang diperoleh pada saat pengukuran pada Tabel 6 dapat disimpulkan bahwa antena yang dipabrikasi mengalami penurunan nilai bandwidth sebesar $24.5 \%$ dari hasil yang diperoleh dari proses simulasi. Hal ini dikarenakan sulitnya untuk mengatur jarak yang presisi untuk celah udara (air gap), perubahan sedikit saja pada celah air gap akan menghasilkan bandwidth yang berbeda. Antena yang dipabrikasi mengalami pergeseran rentang frekuensi kerja yang juga disebabkan oleh kondisi ketidaksesuaian impedansi antara antena dan konektor serta penggunaan timah yang juga dapat mengubah nilai kesesuaian impedansi sehingga pergeseran frekuensi terjadi. Selain itu, perbandingan hasil simulasi dan pengukuran dari VSWR pada antena yang telah dipabrikasi dapat dilihat pada Gambar 18.

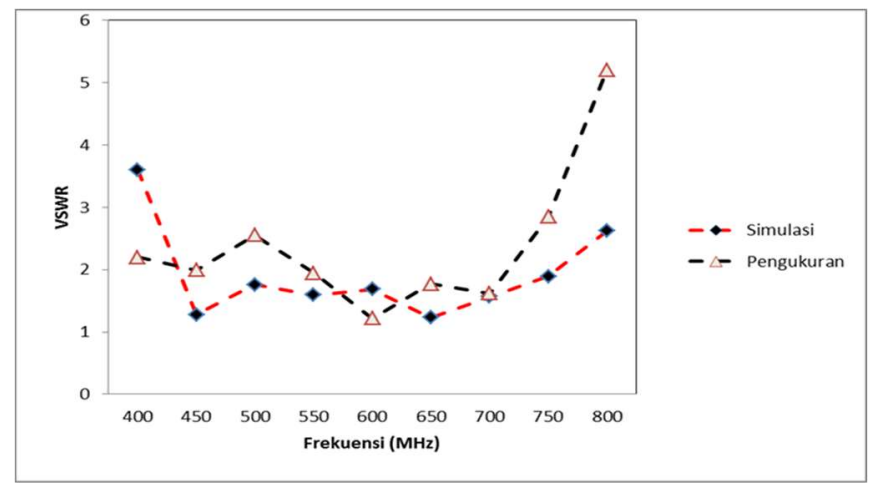

Gambar 18. Perbandingan Hasil Simulasi dan Pengukuran VSWR 
Dari Gambar 18 dapat dilihat bahwa nilai VSWR yang dihasilkan dari proses pengukuran pada frekuensi kerja tertentu mengalami peningkatan namun pada titik lain mengalami penurunan. Perbandingan keseluruhan dari proses pengukuran dan simulasi VSWR pada antena yang dipabrikasi dapat dilihat pada Tabel 7 di bawah ini.

Tabel 7. Perbandingan Nilai Simulasi dan Pengukuran VSWR

\begin{tabular}{|c|c|c|}
\hline Frequency (MHz) & \multicolumn{2}{|c|}{ Nilai VSWR } \\
\cline { 2 - 3 } & Pengukuran & Simulasi \\
\hline 400 & 2.20 & 3.59 \\
\hline 450 & 1.99 & 1.27 \\
\hline 500 & 2.55 & 1.76 \\
\hline 550 & 1.94 & 1.59 \\
\hline 600 & 1.21 & 1.69 \\
\hline 650 & 1.77 & 1.23 \\
\hline 700 & 1.62 & 1.56 \\
\hline 750 & 2.85 & 1.89 \\
\hline 800 & 5.20 & 2.62 \\
\hline
\end{tabular}

Dari hasil perbandingan yang ditunjukkan pada Tabel 7 dapat dilihat bahwa untuk nilai VSWR hasil pengukuran lebih baik dari simulasi. Nilai VSWR pada frekuensi kerja $600 \mathrm{MHz}$ mengalami peningkatan sebesar $39.7 \%$ dari hasil simulasi. Hal ini dikarenakan terjadinya pergeseran rentang frekuensi kerja pada antena mikrostrip yang dipabrikasi sehingga menyebabkan nilai return loss dan VSWR meningkat.

Selain itu dilakukan proses perbandingan antena mikrostrip log periodik sebelum dan sesudah menggunakan elemen parasitik dengan air gap. Gain dari antena log periodik tanpa parasitik dengan celah udara didapatkan dari penelitian sebelumnya adalah $11.62 \mathrm{~dB}$ diperoleh dari penelitian sebelumnya yang dilakukan oleh (Surjati I, Ningsih YK, Alam S, 2017). Adapun hasil perbandingan dari kedua antena tersebut dapat dilihat pada Tabel 8.

Tabel 8. Perbandingan Nilai Simulasi dan Pengukuran Gain

\begin{tabular}{|c|l|c|}
\hline No & \multicolumn{1}{|c|}{ Jenis Antena } & Gain \\
\hline 1. & Log Periodik Biasa & $11.62 \mathrm{~dB}$ \\
\hline 2. & Log Periodik dengan parasitik celah udara & $16.27 \mathrm{~dB}$ \\
\hline
\end{tabular}

Dari hasil perhitungan di atas dapat disimpulkan bahwa penambahan elemen parasitik air gap meningkatkan nilai gain sampai dengan $40.02 \%$ dibandingkan antena log periodik biasa. Peningkatan nilai gain sudah memenuhi kriteria yang ditargetkan yaitu gain $15 \mathrm{~dB}$ dan layak untuk digunakan sebagai antena penerima TV Digital.

\section{KESIMPULAN}

Penelitian ini telah berhasil merancang dan merealisasikan antena mikrostrip log periodik yang dikembangkan dengan metode parasitik celah udara yang bekerja pada rentang frekuensi kerja 478-694 MHz untuk aplikasi TV Digital. Dari hasil pengukuran diperoleh nilai return loss sebesar $-20.27 \mathrm{~dB}$ dan VSWR sebesar 1.21 pada frekuensi kerja $600 \mathrm{MHz}$. 
Frekuensi kerja pada antena mikrostrip yang dipabrikasi mengalami pergeseran dari $586 \mathrm{MHz}$ menjadi $600 \mathrm{MHz}$ namun masih dalam rentang frekuensi kerja TV Digital. Bandwidth yang dihasilkan dari antena mikrostrip log periodik dengan elemen parasitik air gap adalah 273 $\mathrm{MHz}$ (461 MHz - $734 \mathrm{MHz}$ ) sesuai dengan standar kebutuhan rentang frekuensi TV digital di Indonesia yaitu $478-694 \mathrm{MHz}$. Penggunaan metode parasitik dengan air gap berhasil menghasilkan nilai gain sebesar $16.27 \mathrm{~dB}$ atau meningkat sebesar $40.02 \%$ dibanding sebelum menggunakan parasitik air gap pada rentang frekuensi kerja $600 \mathrm{MHz}$. Dari keseluruhan proses simulasi dan pengukuran dapat disimpulkan bahwa antena yang dirancang telah memenuhi kriteria dan cocok untuk digunakan sebagai antena penerima pada sistem TV Digital.

\section{UCAPAN TERIMA KASIH}

Ucapan terima kasih kami sampaikan kepada Lembaga Penelitian Universitas Trisakti yang telah membiayai penelitian ini melalui Hibah Internal tahun akademik 2017/2018.

\section{DAFTAR RUJUKAN}

Alam, S., Wibisana, I. G. N. Y., \& Surjati, I. (2017). Miniaturization of array microstrip antenna using peripheral slits for wireless fidelity communication. In Quality in Research (QiR): International Symposium on Electrical and Computer Engineering, 2017 15th International Conference on, (pp. 91-95).

Candra, H. (2013). Desain Antena Kubikal 600 MHz Sebagai Antena Penerima Siaran Televisi Indoor/Outdoor. Penelitian Kemitraan YPPTI. Universitas Trisakti.

Jacob Abraham, Thomaskutty Mathew, Chandroth K. Aanandan. (2016). A Novel Proximity Fed Gap Coupled Microstrip Patch Array. Progress In Electromagnetics Research C, 61, 171-178.

Kemenkominfo. (2011). PERMENKOMINFO No. 23/PER/M.KOMINFO/11/2011. Rencana Induk (Masterplan) Frekuensi Radio Untuk Keperluan Televisi Siaran Digital Terestrial Pada Pita Frekuensi Radio 478 - $694 \mathrm{MHz}(1-10)$. DKI Jakarta: Kominfo.

Kemenkominfo. (2012). Indonesia Goes Digital Komunikasi Informasi. Seminar Kementrian Komunikasi Dan Informatika Direktorat Jenderal Penyelenggaraan Pos Dan Informatika, (pp. 1-15).

Kemenkominfo. (2012). PERMENKOMINFO No. 05 / PER / M.KOMINFO / 02/2012. Dalam Standar Penyiaran Televisi Digital Terestrial Penerimaan Tetap Tidak Berbayar (FreeTo-Air). (Vol. 1-3). 
Mrnka M, Raida Z. (2016). Gain improvement of higher order mode dielectric resonator antenna by thin air gap. InBroadband Communications for Next Generation Networks and Multimedia Applications (CoBCom), International Conference on 2016, (pp. 1-3).

Rahim, M. K. A., \& Gardner, P. (2004). Microstrip log periodic antenna (LPA) using inset feed. In Antenna Technology and Applied Electromagnetics and URSI Conference, 2004. ANTEM 2004, (pp. 1-4).

Stutzman WL, Thiele GA. (2013). Antenna theory and design. John Wiley \& Son.

Surjati I, Ningsih YK, Alam S. (2017). Peripheral Slits Microstrip Antenna Using Log Periodic Technique for Digital Television Broadcasting. TELKOMNIKA (Telecommunication Computing Electronics and Control), 15(2), 628-635.

Surjati, I. (2010). Antena Mikrostrip: Konsep dan Aplikasinya. DKI Jakarta: Universitas Trisakti.

Teguh Firmansyah, Herudin, Romi Wiryadinata, M.Iman Santoso, Yus Rama Denny, Toto Supriyanto. (2017, September). Bandwidth and Gain Enhancement of MIMO Antenna Using Ring and Circular Parasitic with Air-Gap. TELKOMNIKA, 15(3), 1155-1163.

Wijanto E, Alam S, Harsono B. (2018). Realisasi dan Pengujian Antena Mikrostrip Array 4 Elemen dengan Polarisasi Melingkar untuk Aplikasi 4G/LT. ELKOMIKA: Jurnal Teknik Energi Elektrik, Teknik Telekomunikasi, \& Teknik Elektronika, 6(2), 244.

Wong, K. L. (2004). Compact and broadband microstrip antennas (Vol. 168). John Wiley \& Sons. 